\title{
DEMNITATEA EMBRIONULUI UMAN PERSPECTIVE LITURGICE
}

\author{
Mihail-Liviu DiNU*
}

\begin{abstract}
The demnity of human embrio. From a liturgical point of $v_{i e w}$. The right to live seems to be a right that has been won from centuries for humanity. The human embryo came into contemporary interdisciplinary debate, involving medicine, bioethics, philosophy, ethics, and Christian theology. The current development of scientific research, particularly the biotech industry has put on the current debate the right to live before birth. In the Christian life, even from the beginning of the book Genesis the human life was created and protected by God's divine 'hands', and after the initial creation of the human person, men and women are obeyed to fulfil the divine plan to promote and to transmit the life on earth. The Holy Scripture does not address directly to the embryos, and that does not mean that they were not important because the early church considers the human life sacred and inviolable from the moment of conception. The purpose of this study is to explore the liturgical life of the Church and in the Christian calendar, we observe several Christian celebrations related to holly persons before their birth. We consider that, to be the starting point for developing the liturgical arguments for honouring and respecting human embryo. Furthermore, we are looking into the embryonic iconography of incarnation and the theology of incarnation from the bioethical perspective.
\end{abstract}

Keywords: human embryo, liturgical life, embryonic iconography, protecting life.

“Priest, PhD Student, Faculty of Orthodox Teology at „1 Decembrie 1918” University, Alba Iulia, Romania.

${ }^{1}$ Studiu redactat sub îndrumarea Prof. Univ. Dr. Daniel Munteanu, care şi-a exprimat acordul pentru publicare. 


\section{Introducere}

Încă de la începutul cărții Genezei vedem că viața umană este creată și protejată de „mâinile” lui Dumnezeu. După crearea persoanei umane, femeile și bărbații au datoria să împlinească planul dumnezeiesc de a transmite viața pe Pământ. Cu toate că Sfânta Scriptură nu vorbește direct despre demnitatea embrionilor umani, asta nu înseamnă că ei nu sunt importanți. Biserica a crezut dintotdeauna că viața umană este sacră și inviolabilă încă din momentul concepției. Dacă vom căuta mai adânc în viața liturgică a Bisericii și în calendarul creștin, vom observa sărbători ale zămislirii persoanelor sfinte.

Termenul de ,zămislire” provine din limba slavonă: zamisliti, (astăzi păstrat cu fidelitate în limba sârbă) și înseamnă: a concepe, $a$ conceptualiza; însă sensul cel mai potrivit este cel legat de gestație, adică de momentul însărcinării unei femei, iar aici ne vom referi cu precizie la momentul concepției. În terminologia și învățătura de credință creștină romano-catolică, termenul are o însemnătate mai deosebită, fiind legat și de numele sărbătorii Neprihănitei Zămisliri, în calendarul romano-catolic serbată la data de 8 decembrie, din care se va dezvolta în secolul al XVIIIlea, sub pontificatul papei Clement al XI-lea, dogma Imaculatei concepții, exprimând un omagiu adus nevinovăției desăvârșite, de la zămislire, a Maicii Domnului.

În paginile Vechiului Testament vedem că zămislirea sau concepția este un moment sfințit prin rugăciune comună, de pildă, aşa cum procedează Tobie dreptul și soția lui înainte de a împărți patul conjugal ${ }^{2}$. Vedem astfel că înainte de nașterea copilului, părinții sunt datori să se pregătească duhovnicește, pentru că iau parte la actul creator al lui Dumnezeu și vor da început unei noi persoane umane. Se afirmă metaforic că părinții au pus din sufletul lor o părticică în copil, deoarece ei transmit în mod ereditar nu doar însuşirile fizice, ci și pe cele duhovnicești ${ }^{3}$.

2 „Iar când au rămas numai amândoi în cameră, Tobie s-a sculat din pat și a zis: Scoală, soro, să ne rugăm ca să ne miluiască Domnul!" (Tob. 8, 4).

3 Konstantin V. ZoRIN, Păcatele părinților şi bolile copiilor, trad. Adrian și Xenia Tănăsescu, București, Edit. Sophia, 2007, p. 52-53. 


\section{Calendarul creștin}

În terminologia liturgică și în calendarul bisericesc observăm câteva sărbători care sunt închinate persoanelor sfinte, precum: Zămislirea Sfântului Prooroc Ioan Botezătorul ${ }^{4}$, în data de 23 septembrie, pomenirea zămislirii Preasfintei Născătoarei de Dumnezeu de către Sfânta Ana, în data de 9 decembrie şi Buna Vestire, ce reprezintă zămislirea Mântuitorului nostru Iisus Hristos, în data de 25 martie. Toate aceste sărbători sunt strâns legate de momentul concepției persoanelor respective și evident că au o deosebită importanță din moment ce sunt celebrate liturgic. Chiar potrivit textelor liturgice, concepția este rodul rugăciunii stăruitoare a părinților, în cadrul căsătoriei: „Din pântece sterp a răsărit astăzi rodul rugăciunii, Ioan Mergătorul înainte" ${ }^{5}$ sau în cadrul vecerniei zămislirii Născătoarei de Dumnezeu, auzim la Stihoavnă: „Ana harului cel dumnezeiesc rugându-se oarecând pentru copil striga către Dumnezeu și Ziditorul a toate: Doamne Savaot știi defăimarea pe care o am de pe urma lipsei de fii..."”, de unde vedem că în cadrul tradiției iudaice lipsa copiilor este asociată și cu lipsa binecuvântării divine, adică Dumnezeu „Ị̂si întoarce Fața” de la familia respectivă.

\section{Dreptul de naștere în Vechiul Testament}

Despre statutul femeilor trebuie să spunem că în vechime, în mijlocul poporului evreu, femeia se bucura de anumite privilegii, spre deosebire de popoarele antichității, potrivit poruncii Decalogului: „Cinstește pe tatăl tău şi pe mama ta, ca să-ți fie bine și să trăiești ani mulți pe pământul pe care Domnul Dumnezeul tău ți-1 va da ție” (Ieș. 20, 12). Sau: „Femeile înțelepte zidesc casa, iar cele nebune o dărâmă cu mâna lor" (Pilde 14, 1).

În perioada veterotestamentară, nașterea de copii era foarte importantă, iar acest semn văzut al binecuvântării lui Dumnezeu va conduce la apariția poligamiei, despre care Biblia menționează, primul astfel de caz fiind cel al lui Lameh $($ Fac. 4,19$)$ un urmaș al lui Cain care

\footnotetext{
${ }^{4}$ „Nu te teme Zaharie, rugile tale au fost ascultate și femeia ta Elisabeta îți va dărui un fiu pe care îl vei numi Ioan" (Lc. 1, 13-14).

$5 * * *$ Minei luna septembrie, București, EIBMBOR, 1929, p. 274.

6 ***Minei luna decembrie, București, EIBMBOR, 1991, p. 11.
} 
își ia două soții. Mult mai important este cazul patriarhului Avraam care, fiindcă nu avea urmași, 1-a conceput pe Ismael cu roaba Agar,. Însă Dumnezeu va binecuvânta și pântecele soției sale Sarra, din care se va naște Isaac, adevăratul său moștenitor.

\section{Viziunea neotestamentară asupra ,zămislirii” persoanei umane}

Nașterea de copii în perioada anterioară creștinismului avea ca scop umplerea pământului, pe când căsătoria creștină are ca scop umplerea Bisericii lui Hristos pe Pământ și în Cer, în concluzie - umplerea Raiului ${ }^{7}$.

Potrivit învățăturii creștine, Sărbătoarea Buneivestiri face posibilă Euharistia: întruparea Domnului, zămislirea Sa, este sămânța care cultivă grâul și vinul, trupul și sângele Domnului. În Liturghia ortodoxă se începe cu zămislirea Domnului, cu întruparea Sa. Putem lega această imagine a icoanei Buneivestiri, zugrăvită simetric pe Ușile Împărătești ale Sfântului Altar, de gestul liturgic al deschiderii $\operatorname{lor}^{8}$ şi de gestul liturgic în care preotul vine și Îl face posibil pe Hristos credincioșilor, împărtășindu-i între aceste uși deschise.

Pe de altă parte, este de remarcat faptul că doar trei persoane în cadrul calendarul liturgic ortodox se bucură de sărbătoarea zămislirii: Maica Domnului, Sfântul Ioan Botezătorul și, bineînțeles, Mântuitorul nostru Iisus Hristos, iar acestora iconografia bisericească le oferă registrul Deisis, care înseamnă rugăciune. Astfel, în structura simbolică a icoanei Deisis se arată locul deosebit al Maicii lui Dumnezeu și al Înaintemergătorului Ioan în jurul lui Hristos ${ }^{9}$ în , „în calitate de primi martori direcți ai Întrupării Sale: Maica Sa și respectiv cel care «a săltat

${ }^{7}$ Sfântul Nicolae Velimirovici, Credința Sfinților. Catehismul Bisericii Ortodoxe, trad. Petre -Valentin Lică, București, Edit. Biserica Ortodoxă, 2004, p. 34.

${ }^{8}$ Acest lucru ne duce cu gândul la troparul Buneivestiri unde se zice: „Astăzi este începătura mântuirii noastre și arătarea tainei celei din veac: Fiul lui Dumnezeu - Fiu Fecioarei se face și Gavriil Darul bine îl vestește...", *** Minei luna martie, București, EIBMBOR, 1994, p. 391.

${ }^{9}$ Elisabeta NEGRĂU, „Deisis în pictura românească a secolelor XIV-XVIII. Teme şi semnificații”, în Revista Teologică, vol. 93, nr. 2/2011, Mitropolia Ardealului, Facultatea de Teologie Ortodoxă „Andrei Şaguna”, Sibiu, p. 48. 
de bucurie în pântecele mamei sale» $(\text { Lc. } 1,41)^{10}$ atunci când L-a întâlnit pe Dumnezeu întrupat", astfel că icoana Deisis devine o teofanie care ,însumează toate caracterele persoanei lui Hristos întrupat, înviat și înălțat la cer"11. Dacă vom observa din punct de vedere liturgic icoana Deisis, atunci icoana zămislirii prin rugăciune este redată în Proscomidie, în pregătirea darurilor, unde atât Maica Domnului, cât și Sfântul Ioan Botezătorul stau de o parte și de cealaltă a Sfântului Agneț.

Revenind la icoana Buneivestiri, Părintele Stăniloae spune că unul dintre meritele creștinismului este acela de a restabili demnitatea femeii, în sensul că, deși rolurile lor rămân potrivit aptitudinilor specifice, totuși, în iconomia treimică „Fiul lui Dumnezeu binevoiește a se face Fiul femeii”. În consecință, femeia nu mai poate rămâne în istorie pe plan secund, ci primește rolul de a fi Maică a Cerului, ființă celestă, și putem spune că în acest act bărbatului i se cuvine rolul secund ${ }^{12}$, atât timp cât sa dispensat de bărbat în actul Întrupării ${ }^{13}$.

Stăniloae insistă asupra celei de-a doua urmări a unirii ipostatice: nașterea supranaturală a lui Iisus Hristos și pururea fecioria Mariei, spunând că nașterea supranaturală este o inițiativă a lui Dumnezeu și nu a omului ${ }^{14,}$ acest act realizându-se printr-o nouă intervenție a lui Dumnezeu, însă nu ca o nouă creație. Această intervenție își are originea într-o femeie, Dumnezeu urmărind refacerea naturii și nu distrugerea e ${ }^{15}$. Atât timp cât bărbatul, prin structura autorității patriarhale ${ }^{16}$, este cel

10 În calendarul Bisericii Romano-Catolice se păstrează și Sărbătoarea Vizitei Sfintei Fecioare Maria la vara ei Elisabeta, prăznuită în data de 31 mai.

${ }^{11}$ Elisabeta NEGRĂU, „Deisis în pictura românească a secolelor XIV-XVIII. Teme și semnificații”, p. 48.

${ }^{12}$ Contrar eticii aristotelice a lui Toma de Aqino, că femeia este mas occasionatus.

${ }^{13}$ Dumitru Stăniloae, Iisus Hristos sau restaurarea omului, Craiova, Edit. Omniscop, 1993, p. 166.

${ }^{14}$ Ibidem, p.160.

${ }^{15}$ Ibidem, p 161.

${ }^{16}$ Structura autorității patriarhale pierde sensul omului religios - homo religiosus și îl dezvoltă pe homo faber, care îl înlocuiește pe homo sapiens datorită faptului că inteligența devine abilitatea de a construi obiecte artificiale, iar acum animalul inteligent posedă mașini sau ustensile necesare evoluției (Henri BERGSON, Creative Evolution, New York, Cosimo Classics, 2005, p. 153-154; Larry A. HICKMAN, John Dewey's pragmatic technology, Indiana University Press, Bloomington and Indianapolis, 1992, p. 116.) 
care deturnează existența de la structura ei, feminitatea reprezintă, după părerea părintelui Stăniloae, partea mai pasivă și mai receptivă a omenirii1 ${ }^{17}$, iar Maria a corespuns hotărârii divine de înfăptuire a întrupării Logosului ${ }^{18}$. Însă nu trebuie să reducem rolul femeii la o pasivitate inertă, ci participarea ei se face prin ascultare, puritate și slujire. Această slujire îi oferă în teologia ortodoxă calitatea de arhetip al femininului și Sfântul Ioan Gură de Aur numește Buna Vestire „Praznic al Rădăcinii” ${ }^{19}$ noului eon.

\section{Legătura duhovnicească şi genetică între părinte și copil}

Legătura duhovnicească și genetică între părinte și copil este redată de Sfânta Scriptură prin exemplul regelui David, care s-a căsătorit cu Batşeba, soția generalului Urie, pe care 1-a trimis la moarte pe câmpul de luptă. Din legătura celor doi se naște un copil căruia îi este prorocit, prin prorocul Natan, că va muri. Cu toate că David se pocăiește cu amar, nădăjduind că astfel copilul o să scape, totuşi după cum zice Scriptura: „fiecare este ispitit când este tras și momit de însăşi pofta sa. Apoi pofta, zămislind, naște păcat, iar păcatul, odată săvârșit, aduce moarte" (Iac. 1, 14-15). După care, datorită pocăinței lor, Dumnezeu le dăruiește pe Solomon, un model de slavă, cinste și înțelepciune, până spre finalul vieții, când datorită închinării la idoli și desfrânării.

Astfel, observăm că în tradiția creștină părinții sunt chemați să-și asume răspunderea pentru sănătatea duhovnicească și psihofizică a copiilor. Și astfel este interesant de făcut o comparație între recomandările medicale și cele duhovnicești în ceea ce privește perioada premergătoare sarcinii, dar şi în timpul sarcinii.

17 În lucrările unor Sfinți Părinți și ale reformatorilor, dar și în teologia dialectică a lui Karl Barth, există o varietate largă de declarații sexiste afirmând că femeile sunt slabe, inferioare, receptive și pasive (Karen OFFEN, „Defining feminism: A Comparative Historical Approach", în rev. Signs, Vol. 14, No. 1, The University of Chicago Press, autumn, 1988, p. 126). După alții, femeile sunt văzute ca Halb-Mensch, în sensul că ele ar fi jumătatea pasivă a umanității - a se vedea: Leonard Swidler, ,Jesus Begegnung mit Frauen: Jesus als Feminist", în vol. Frauenbefreiung. Biblische und teologische Argumnete, hrsg. von Elisabeth Moltmen Wendel, 3, Auflange, Kaiser Grünewald Verlag, München, Maintz, 1982, - părere care influențează și teologia părintelui Stăniloae - Dumitru STĂNILOAE, Iisus Hristos sau restaurarea omului, p. 162.

18 Ibidem.

${ }^{19}$ Paul Evdokimov, Femeia și mântuirea lumii, p. 267. 
Konstantinos V. Zorin evidențiază din punct de vedere etic această pregătire duhovnicească pe perioada sarcinii, pentru femeile gravide; el atrage atenția asupra problemelor etice în ceea ce privește căsătoriile cosangvine, bolile infecțioase cu transmitere sexuală, fumatul, alcoolismul și narcomania ${ }^{20}$.

Despre căsătoriile cosangvine, Legea Veche dată prin Moise le interzice evreilor să urmeze obiceiurile Egiptului și ale Canaanului: „,De datinile pământului Egiptului, în care ați trăit, să nu vă țineți, nici de datinile pământului Canaanului...Nimeni să nu se apropie de nici o rudă după trup, cu gândul ca să-i descopere goliciunea" (Lev. 18, 3, 6). Aici urmează o enunțare a relațiilor nepotrivite descrise în întreg cuprinsul capitolului.

De altfel și știința medicală spune că ,unele din tulburările genetice sunt transferate recesiv autozomal în indivizii purtători și cosangvinitatea facilitează maparea homozigotă a acestor boli genetice, care apar la descendenții lor" 21 printre acestea numărându-se: cancerul, bolile mentale, hipertensiunea arterială, deficiențe ale inimii, diabet, epilepsie, astm sau leucemie. Deci oricât ar părea de ciudat, înrudirea genetică între tată şi mamă au ca efect expulzarea şi afectarea embrionului uman.

Sănătatea mamei este importantă în creșterea intrauterină a copilului, astfel că nu este recomandat tratamentul administrat femeii gravide pentru că acesta nu este nicidecum lipsit de toxicitate, datorită faptului că medicamentele pătrund în organismul acesteia și trec prin placentă, prin lichidul amniotic și chiar, în cele din urmă, prin laptele de la sân. Pot astfel interveni tulburări ale diverselor organe și țesuturi sau defecte de dezvoltare.

Alcoolismul este un factor care influențează fătul în funcție de stadiul dezvoltării intrauterine astfel, chiar înainte de fertilizare, alcoolul produce vătămarea spermatozoizilor și ovulelor, iar de la concepție până

${ }^{20}$ Konstantinos V. ZoRIN, Păcatele părinților și bolile copiilor, p. 56.

${ }^{21}$ Nommanudien NAIBKHIL, Ekta CHITKARA, „Consanguineous marriages increase risk of congenital anomalies-studies in four generation of an afghan family", în Biomedical Research, Volume 27, Issue 1/ 2016, pe site-ul: http://www.alliedacademies.org/articles/consanguineous-marriages-increase-risk-ofcongenital-anomaliesstudies-in-four-generation-of-an-afghan-family.html (accesat la data de 04.12.2018). 
în săptămâna a noua este perioada de formare intensivă a organelor și țesuturilor, din săptămâna a noua până la sfârșitul sarcinii continuă să se formeze organele principale ale copilului, creierul și organele sexuale, creșterea acestora putând fi încetinită datorită alcoolismului ${ }^{22}$. Potrivit recomandărilor scripturistice: „Iată ai să zămislești și ai să naști un fiu; așadar să nu bei vin și sicheră și să nu mănânci nimic necurat, căci copilul chiar din pântecele mamei și până la moarte va fi nazireu al lui Dumnezeu" (Jud. 13, 7).

În teologia ortodoxă zămislirea și nașterea pruncilor sunt niște momente deosebit de importante, în primul rând pentru că acestea nu sunt văzute în afara căsătoriei consfințită de Dumnezeu. Familia este locul în care concepția copiilor este văzută ca binecuvântare, iar nașterea copiilor este, pe lângă legătură fizică, și produs al rugăciunii omului.

\section{Concluzii}

Prin cateheza experențială a Liturghiei Ortodoxe, abordăm conceperea persoanei umane din perspectiva experierii personale împărtășite nouă. De asemenea, vedem că aceste sărbători ale zămislirii constituie atât o întâlnire prin rugăciune a omului cu Dumnezeu, cât și o piatră de temelie pentru dialogul cu biotehnologiile contemporane ale reproducerii.

Potrivit teologiei ortodoxe, prin întruparea lui Iisus Hristos, Dumnezeu Se unește deplin cu fiecare om. Efectele Întrupării asupra umanitătii sunt ireversibile. De la Întrupare taina omului nu mai poate fi privită fără lumina acestui eveniment istoric unic. Umanitatea lui Dumnezeu nu este absorbită de dumnezeirea Sa, sau, în cuvintele lui Pietro Coda: ,taina Întrupării este misterul umanizării complete a omului, care nu se opune divinității sale, ci este o relație reciprocă om-Dumnezeu, unit și în același timp distinct în Hristos"23.

Într-un sens tipologic, Adam, primul bărbat, este văzut ca imaginea lui Iisus „ultimul Adam”. Aceasta ne indică în mod eshatologic „noul

${ }^{22}$ Konstantinos V. Zorin, Păcatele părinților și bolile copiilor, p. 61.

23 Pietro CODA, „L'uomo nel mistero di Cristo e della Trinità. L'antropologia della "Gaudium et spes»", Lateranum 54:1 (1988), p. 164-194, apud. Leonard de Chirico, The Dignity of the Human Person. Towards an Evangelical Reading of the Theology of Personhood of Vatican II, Evangelical Quarterly, p. 250. 
Om”. Relația intrinsecă dintre cei doi Adami ne face să afirmăm că însuşirile sau calitățile interioare ale primului Adam își găsesc rădăcina și se împlinesc în ultimul Adam; într-un fel, putem spune că tot ceea ce nu a reușit primul Adam reușește Hristos. Adam cel eshatologic îl salvează și îl scoate la lumină pe Adam cel protologic, schimbând cursul istoriei, împlinind scopul și ceea ce Dumnezeu a dorit pentru om, astfel că oricine Îl urmează pe Hristos, noul Adam și omul cel desăvârșit, ia și el parte la această umanitate transfigurată și desăvârșită la adevărata ei potență ${ }^{24}$.

Noua antropologie este, după cuvintele lui Paul Evdokimov: „Știința stăpânirii duhovnicescului asupra a ceea ce este material, fără să lase nicicând de o parte planul cel mai concret al existenței" ${ }^{25}$, este o antropologie ascetică care salvează lumea de cele mai îngrozitoare înfumurări: autoritmia (suficiența de sine) și autopistia (credința în sine însuşi), prin dimensiunea jertfei și a rugăciunii, unde omul își descoperă „prinosul ființei sale”,26, sau sensul demnității sale protologice.

\section{Referinţe bibliografice:}

1. *** Minei luna martie, EIBMBOR, București, 1994;

2. *** Minei luna septembrie, EIBMBOR, București, 1929;

3. ***Minei luna decembrie, EIBMBOR, București, 1991;

4. Abrudan, Dumitru, Cornițescu, Emilian, Arheologia Biblică, Sibiu, EIBMBOR, 2002;

5. AMERICAN ACADEMY of PEDIATRICS, AMERICAN COllege of OBSTETRICIANS and GYNECOLOGISTS, Guidelines for perinatal care. 8th ed. Elk Grove Village (IL): AAP; Washington, DC: American College of Obstetricians and Gynecologists; 2017;

6. Bergson, Henri, Creative Evolution, New York, Cosimo Classics, 2005;

7. CHIRICO, Leonardo de, The Dignity of the Human Person. Towards an Evangelical Reading of the Theology of Personhood of Vatican II, Evangelical Quarterly, LXXVII, nr 3 / 2005;

${ }^{24}$ Leonardo de CHIRICO, The Dignity of the Human Person. Towards an Evangelical Reading of the Theology of Personhood of Vatican II, Evangelical Quarterly, LXXVII, nr 3 / 2005, p. 249-259.

${ }^{25}$ Paul Evdokimov, Ortodoxia, trad. Irineu Ioan Popa, București, EIBMBOR, 1996, p. 25.

${ }^{26}$ Ibidem. 
8. Evdokimov, Paul, Femeia și mântuirea lumii, trad. Vasile Răducă, București, Edit. Christiana, 1995;

9. Hickman, Larry A., John Dewey's pragmatic technology, Indiana University Press, Bloomington and Indianapolis, 1992;

10. NAIBKHIL, Nommanudien, CHITKARA, Ekta, „Consanguineous marriages increase risk of congenital anomalies-studies in four generation of an afghan family", în Biomedical Research, Volume 27, Issue 1/ 2016, pe site-ul http://www.alliedacademies.org/articles/consanguineousmarriages-increase-risk-of-congenital-anomaliesstudies-in-fourgeneration-of-an-afghan-family.html, accesat la data de 04.12.2018;

11. NEGRĂU, Elisabeta, „Deisis în pictura românească a secolelor XIVXVIII. Teme și semnificații”, în Revista Teologică, vol. 93, nr. 2/ 2011, Mitropolia Ardealului, Facultatea de Teologie Ortodoxă „Andrei Şaguna", Sibiu;

12. SPERLING, Connor EM, GELBER RS, KISELEV R, Reduction of maternalinfant transmission of human immunodeficiency virus type 1 with zidovudine treatment, Pediatric AIDS Clinical Trials Group Protocol 076 Study Group. N Engl J Med. Nov; 331, 18/ 1994;

13. STĂNILOAe, Dumitru, Iisus Hristos sau restaurarea omului, Craiova, Edit. Omniscop, 1993;

14. Sfântul Nicolae Velimirovici, Credința Sfinților. Catehismul Bisericii Ortodoxe, trad. Petre - Valentin Lică, București, Edit. Biserica Ortodoxă, 2004;

15. ZoRIN, Konstantin V., Păcatele părinților și bolile copiilor, trad. Adrian şi Xenia Tănăsescu, București, Edit. Sophia, 2007. 